\title{
International Human Rights Law in Soviet and
}

\section{American Courts}

\author{
Lori Fisler Damrosch $\dagger$
}

To what extent should domestic courts apply international law-specifically the international law of human rights? I would like to examine this question with reference to two very different states: the Union of Soviet Socialist Republics and the United States. For quite distinct reasons, neither of the two has yet fully embraced the idea of direct application in national tribunals of the body of international law that regulates the relationship between human beings and their own governments. As the post-Cold War era unfolds, it is time to ask whether either or both of these erstwhile adversaries might finally be ready for full-fledged implementation of international human rights law in national courts.

The Soviet Union is going through such profound political and constitutional change that specific comments run the risk of obsolescence or irrelevancy. In early 1991, when this Essay was in preparation, the breakup of the Union came to seem inevitable, but what will emerge cannot yet be foreseen. Retrogressive developments have cast doubt on the prospects for advancing the rule of law under the current Soviet leadership. Nonetheless, I believe that the issue of domestic application of international human rights law will survive the current tumultuous period and will figure in the disposition of transcendent constitutional issues.

The idea of consolidating domestic protection of international human rights is on the ascendant everywhere in the Soviet Union. If the Union splits up into sovereign states consisting of the present republics or comparable units, then the resulting entities will themselves have to deal with the issues explored in this Essay. They may well go about that effort more vigorously than the Union itself. Indeed, the republics, one after another, in their declarations of sovereignty and constitutional documents, have proclaimed commitment to the principles of international law guaranteeing human rights and fundamental freedoms. ${ }^{1}$ If the Union survives, its leaders will not be able to ignore the demands of the

† Professor of Law, Columbia University. The author thanks John N. Hazard, Louis Henkin, Peter H. Juviler, Rein Mullerson, and Gerald L. Neuman for their comments; Mary Holland, Nikolai Krylov, and Vratislav Pechota for materials on recent Soviet developments; and Jonathan W. Narins and Daniel P. Penn, whose capabilities in Russian made them especially valuable research assistants.

1. See infra text accompanying note 4.5 . 
people for institutions to implement internationally protected rights. ${ }^{2}$ The problem of assuring compliance with international obligations concerning human rights is high on the agenda of those preparing new constitutional drafts, and the recently established Committee of Constitutional Supervision has been given a mandate to apply international human rights instruments. ${ }^{3}$ Thus, the issue of domestic implementation of international human rights law figures prominently in political as well as legal debate, ${ }^{4}$ even as controversy swirls over what kind of state-or states-will rise from the ruins of the Soviet Union.

With hindsight, it is easy to see that the international human rights movement helped bring about the changes sweeping the Soviet Union; it will require foresight to develop structures capable of consolidating gains achieved in the human rights field. One such institutional initiative should be movement toward application of international human rights law in domestic tribunals. ${ }^{5}$

In the pages that follow, I first survey the principal sources of international human rights law as they pertain to the Soviet Union and the United States. I then examine the legal infrastructure for giving effect to international law in the Soviet Union, and I note contrasts to the analogous infrastructure in the United States. ${ }^{6}$ The positions taken by these two states reflect quite different attitudes toward law, toward lawmaking processes, and toward the role of courts in applying law. These different attitudes directly affect the two nations' respective approaches to the international law of human rights.

The Soviet Union is at a historical juncture where all prior tenets are open for reexamination, and international human rights law may be able to exert an

2. The formulation of the referendum on national unity held in March of 1991 is illustrative: "Do you consider it necessary to preserve the Union of Soviet Socialist Republics as a renewed federation of equal sovereign republics, in which the rights and freedoms of people of any nationality will be fully guaranteed?" See N.Y. Times, Mar. 19, 1991, at A1, col. 6 (emphasis added). The leadership's draft of a new Union treaty calls upon the republics to recognize "as the most important principle of their association, the priority of human rights proclaimed in the Universal Declaration of the United Nations and in international covenants." Union Treaty: Draft, Third Fundamental Principle [hereinafter Union Treaty Draft] (on file with author).

3. See infra text accompanying notes 54-71.

4. See, e.g., Vereshchetin, Danilenko \& Mullerson, Konstitutsionnaia reforma $v$ SSSR i mezhdunarodnoe pravo (Constitutional Reform in the USSR and International Law), SOVETSKOE GOSUDARSTVO I PRAVO (SOVIET STATE AND LAW), No. 5, 1990, at 13 [journal, hereinafter Sov. Gos. \& PRAVo]; Vereshchetin \& Mullerson, Primat mezhdunarodnogo prava $v$ mirovoi politike (The Primacy of International Law in World Politics), Sov. Gos. \& PRAVO, No. 7, 1989, at 3.

5. My argument applies with equal force to the Soviet Union if it survives as a political entity, or to any future states that may emerge out of a breakup or reorganization.

6. The present readership is presumed to be familiar with the relevant concepts in U.S. law. For a summary, see RESTATEMENT (THIRD) OF FOREIGN RELATIONS LAW OF THE UNITED STATES \$§ 111-115 (1987) [hereinafter RESTATEMENT]; see also Henkin, The Constitution and United States Sovereignty: A Century of Chinese Exclusion and Its Progeny, 100 HARV. L. REV. 853, 863-85 (1987); Henkin, International Law as Law in the United States, $82 \mathrm{MICH}$. L. REV. 1555 (1984). I will confine myself to issues that bear examination in light of developments in the Soviet Union.

This Essay concentrates on application of international human rights law against a state in its own courts and thus does not deal with the problem of suing one state or its officials in the courts of another. A few plaintiffs have sought to invoke the aid of U.S. courts to require the Soviet Union to comply with international human rights law. Compare Frolova v. USSR, 761 F.2d 370 (7th Cir. 1985) (emigration) with Von Dardel v. USSR, 623 F. Supp. 246 (D.D.C. 1985), dismissed, 736 F. Supp. 1 (D.D.C. 1990) (personal security). 
unprecedented influence. At the same time, the transformations in the Soviet Union provide an opportune moment for reconsideration of arguments used to oppose U.S. ratification of human rights treaties. The United States, along with the Soviet Union, should discard Cold War attitudes in the domestic legal sphere as well as in international relations, and should rise to the challenge of providing legal guarantees for the implementation of internationally protected rights.

\section{OVERVIEW OF SOURCES OF INTERNATIONAL HUMAN RIGHTS LAW}

International human rights law is a vast field, and the United States and the Soviet Union have typically emphasized quite different aspects of it. Substantively, its content ranges across the panoply of civil and political rights cherished in the Western European and American traditions as well as the economic and social rights favored by the Soviet Union and other socialist states-from the right to speak one's mind to the "right" to periodic holidays with pay. ${ }^{7}$ Because claimants in domestic tribunals are typically expected to show where a claimed right comes from and why it is legally binding, I will be more concerned with the formal pedigree of internationally protected rights than with their substantive content. A U.S.-Soviet comparison will show that the two countries differ not only in the extent to which they have endorsed the various human rights documents, but also in their attitudes toward the different sources of international law.

In terms of formal sources, international human rights law is found in single-issue, quasi-universal treaties such as the Genocide Convention; ${ }^{8}$ general, multilateral treaties such as the International Covenant on Civil and Political Rights $^{9}$ and the International Covenant on Economic, Social and Cultural Rights; ${ }^{10}$ regional treaties such as the European Convention on Human Rights, ${ }^{11}$ resolutions of the U.N. General Assembly such as the Universal Declaration of Human Rights; ${ }^{12}$ political pledges such as the Helsinki Accords, ${ }^{13}$ and that most elusive species of all, customary international law. ${ }^{14}$

7. For a catalogue of most internationally recognized rights, see Universal Declaration of Human Rights, G.A. Res. 217A, U.N. Doc. A/810 (1948). The rights referred to in the text are found in the Declaration in Articles 19 and 24.

8. Convention on the Prevention and Punishment of the Crime of Genocide, Dec. 9, 1948, S. ExEC. Doc. O, 81 st Cong., lst Sess. 7 (1949), 78 U.N.T.S. 277.

9. Dec. 16, 1966, 999 U.N.T.S. 171.

10. Dec. 16, 1966, 993 U.N.T.S. 3.

11. [European] Convention for the Protection of Human Rights and Fundamental Freedoms, Nov. 4, 1950, 213 U.N.T.S. 221 [hereinafter European Convention].

12. Supra note 7.

13. Conference on Security and Co-operation in Europe: Final Act (Helsinki Accords), Aug. 1, 1975, 14 I.L.M. 1292.

14. See generally RESTATEMENT, sIpra note $6, \S 702$ (containing short list of practices considered violative of customary international law of human rights). 
These various sources are of differing legal significance, and some are more likely to be enforced in domestic courts than others.

A snapshot of U.S. and Soviet adherence to the foregoing categories of instruments would show that the Soviet Union has become party to most of the major U.N.-sponsored treaties and the United States to only a few. ${ }^{15}$ The United States has recently entered reservations requiring specific future consent in order to invoke the jurisdiction of the International Court of Justice to resolve disputes arising under certain human rights treaties, ${ }^{16}$ while the Soviet Union has recently withdrawn comparable reservations previously made with respect to half a dozen such treaties. ${ }^{17}$ Neither state has yet accepted the optional procedures under which individuals could press treaty-based claims before international bodies. ${ }^{18}$ Concerning regional activities, neither state is currently a party to the human rights conventions pertaining to its geographic region-the European Convention for the Protection of Human Rights and Fundamental Freedoms in the case of the Soviet Union, and the American Convention on Human Rights in the case of the United States. ${ }^{19}$ Both states participate in the Conference on Security and Co-operation in Europe (CSCE) which produced the Helsinki Accords in $1975^{20}$ and which has, more recently,

15. For a chart of 24 major human rights instruments, see U.N. CENTRE FOR HUMAN RIGHTS, UNTTED NATIONS, HuMAN Rights: STATUS OF INTERNATIONAL INSTRUMENTS, Mar. 1, 1990, at 12-13, U.N. Doc. ST/HR/5, U.N. Sales No. E.87.XIV.2 (1987 \& chart 1990). The USSR is party to 14 of the 24 instruments, and the United States only to 7 as of the chart's cutoff date. (Subsequently, the U.S. Senate approved ratification of the Torture Convention.) Treaties to which the Soviet Union but not the United States is a party include both of the major International Covenants, supra notes 9-10 and accompanying text, as well as conventions against racial discrimination, apartheid, and discrimination against women.

16. Concerning the Torture Convention, see infra note 18; concerning the Genocide Convention, see 132 CONG. REC. $S 1377$ (daily ed. Feb. 19, 1986). These reservations were adopted in the aftermath of the rulings against the United States in Military and Paramilitary Activities in and Against Nicaragua (Nicar. v. U.S.), 1984 I.C.J. 392 (Nov. 26) (jurisdiction), 1986 I.C.J. 14 (June 27) (merits), which provoked the U.S. government to reassess its position with respect to the Court's compulsory and treaty-based jurisdiction. For background on the U.S. reconsideration, see THE INTERNATIONAL COURT OF JUSTICE AT A CROSSROADS xvii-xxviii (L. Damrosch ed. 1987).

17. See Soviet Union Accepts Compulsory Jurisdiction of ICJ for Six Human Rights Conventions, 83 AM. J. INT'L L. 457 (1989).

18. Such procedures exist, inter alia, in the form of an Optional Protocol to the International Covenant on Civil and Political Rights, Dec. 16, 1966, 999 U.N.T.S. 171. In giving advice and consent to ratification of the Convention Against Torture and Other Cruel, Inhuman or Degrading Treatment or Punishment, opened for signature Feb. 4, 1985, G.A. Res. 39/46, 39 U.N. GAOR Supp. No. 51 at 197, U.N. Doc. A/RES/39/708 (1984), reprinted in 23 I.L.M. 1027 (1984) [hereinafter Torture Convention], the U.S. Senate approved a declaration pursuant to Article 21(1) allowing claims by other states, but the U.S. administration did not seek authority for the optional declaration under Article 22 on individual petitions. See 136 CONG. REC. S17,491-92 (daily ed. Oct. 27, 1990). Since only states can be parties to cases before the International Court, see Statute of the International Court of Justice, art. 34(1), 59 Stat. 1055, 1059 T.S. 933, that Court does not provide a forum for individual petitions.

19. The European Convention, supra note 11, is open to members of the Council of Europe (art. 66). The Soviet Union and other East European states are not members of the Council; how they might qualify is an issue of some uncertainty and controversy. According to Article 3 of the Statute of the Council of Europe, May 5, 1949, 87 U.N.T.S. 103, 106, every member "must accept the principles of the rule of law and of the enjoyment by all persons within its jurisdiction of human rights and fundamental freedoms." Concerning the American Convention on Human Rights, see 9 I.L.M. 101, 673 (1970).

20. Supra note 13. 
adopted major new statements of human rights principles-at Vienna in 1988 and at Copenhagen and Paris in $1990 .^{21}$ These undertakings, however, are generally considered "political" rather than "legal." 22

Treaty ratification is not the only method for giving legal life to international human rights law. In the United States, advocates have adopted creative strategies in attempting to infuse concepts of the international movement into American jurisprudence, but their success has been limited. ${ }^{23}$ Without attempting to do justice to the burgeoning scholarship in this area, I draw attention to efforts to use international concepts as part of the backdrop for constitutional interpretation, ${ }^{24}$ as well as efforts to establish that certain human rights norms have crystallized into customary law binding on all states, even those that have not ratified the relevant treaties. ${ }^{25}$ The efforts to implement international human rights law in the Soviet Union have taken a substantially different approach and will be examined in detail below.

\section{SOVIET APPROACHES TO APPLICATION OF INTERNATIONAL LAW}

\section{A. Background}

It is a fair generalization to say that Soviet courts have little experience in applying international law, whether derived from treaties or otherwise. The idea of international law as part of "the law of the land," while familiar to Western lawyers, is foreign to Soviet jurisprudence. To be sure, the 1977 Soviet Constitution declared that "the USSR's relations with other states are based on ... fulfillment in good faith of obligations arising from the generally recognised principles and rules of international law, and from the international treaties signed by the USSR." ${ }^{26}$ But in contrast to the United States, where treaties

21. CSCE: Concluding Document from the Vienna Meeting, Nov. 4, 1986-Jan. 17, 1989, 28 I.L.M. 527; CSCE: Document of the Copenhagen Meeting of the Conference on the Human Dimension, June 29, 1990, 29 I.L.M. 1305 [hereinafter Copenhagen Document]; Charter of Paris for a New Europe, Nov. 21, 1990, 30 I.L.M. 193.

22. Russell, The Helsinki Declaration: Brobdingnag or Lilliput?, 70 AM. J. INT'L L. 242, 246-49 (1976); Schachter, The Twilight Existence of Nonbinding International Agreements, 71 AM. J. INT'L L. 296, 296-97 (1977). Soviet scholars concur that the Helsinki Final Act is considered politically rather than legally binding. See Mullerson, Sources of International Law: New Tendencies in Soviet Thinking, 83 AM. J. INT'L L. 494, 509-12 (1989).

23. See Tolley, Interest Group Litigation to Enforce Human Rights, 105 POL. SCl. Q. 617 (1990-1991).

24. E.g., Thompson v. Oklahoma, 487 U.S. 815,830 n.31 (1988) (plurality opinion referring to international practice as relevant to decision on unconstitutionality of applying death penalty statutes to crimes committed by juveniles). But see id. at 868-69 n.4 (Scalia, J., dissenting) (attacking plurality's reliance on international sources as "totally inappropriate"); Stanford v. Kentucky, 492 U.S. 361, 369 n.1 (1989) (majority opinion by Scalia dismissing relevance of international practice).

25. E.g., Garcia-Mir v. Meese, 788 F.2d 1446 (11th Cir.), cert. denied sub nom. Ferrer-Mazorra v. Meese, 479 U.S. 889 (1986) (undocumented aliens invoked customary norm against prolonged detention). The human rights provisions of the United Nations Charter have generally been treated as non-self-executing. See, e.g., Sei Fujii v. California, 38 Cal. 2d 718, 720-25, 242 P.2d 617, 619-22 (1952).

26. KONST. SSSR art. 29 (1977) (USSR Constitution), reprinted in 18 CONSTITUTIONS OF THE COUNTRIES OF THE WORLD 25 (A. Blaustein \& G. Flanz eds. 1990). 
are declared to be the "supreme Law of the Land" 27 and where federal courts are given constitutional and statutory jurisdiction over cases arising under treaties ${ }^{28}$ Soviet courts have not been given explicit authority to apply international law as a direct source of law. Rather, the 1977 Constitution conferred the function of implementing international law upon the Council of Ministers, which is an executive organ, ${ }^{29}$ and upon the respective subsidiary organs that have competence over the subject matter in question. ${ }^{30}$ While Soviet scholars have pointed out that it is not entirely correct to say that Soviet courts have never applied international law, the few contrary examples that they cite would strike Western lawyers as inconsequential. ${ }^{31}$

The Soviet reluctance to apply international law in national tribunals may be traced to several factors. First, the Soviet system has hardly been hospitable to the idea of the rule of law as a control over official action; rather, law has been viewed instrumentally - as a tool for building and maintaining a socialist order. ${ }^{32}$ Only with the advent of perestroika and glasnost have there been serious gestures in the direction of bringing the state itself under the rule of law. ${ }^{33}$ Just as there has been no tradition of constitutional control in the Soviet Union (or in the Russian empire), the idea of applying international law to change what elites or bureaucrats would otherwise do is an alien notion. Second, there is no legal culture of an independent judiciary to give effect to rules that would constrain the government. Rather, Soviet courts and judges have typically served as adjuncts of the party apparatus. ${ }^{34}$

Moreover, international law has not always been fully embraced for domestic application even by constitutional democracies that have a jurisprudence

27. U.S. CONST, art. VI, cl. 2.

28. U.S. CONST. art. III, $\$ 2 ; 28$ U.S.C. $\$ 1331$ (a) (1989). Concerning customary international law in federal courts, see RESTATEMENT, supra note $6, \S 111$.

29. See KONST. SSSR arts. 128, 131(6) (1977) (Council of Ministers, as highest executive and administrative body of state authority of USSR, to take measures to ensure fulfillment of USSR's international treaties).

30. See Law on the Procedure for the Conclusion, Execution, and Denunciation of International Treaties of the USSR, art. 21, translated in W. BUTLER, BASIC DOCUMENTS ON THE SOVIET LEGAL SYSTEM 290 (2d ed. 1988) [hereinafter Law on Treaties].

31. A recent article states:

The view is widespread that Soviet courts generally never take decisions on the basis of norms of international law. It is true that up to the present, by virtue of the decidedly autarkic tendencies of our society as a whole and the "impenetrability" of our legal order in particular, this took place rarely, but in the case of questions of international transportation or the rendering of juridical assistance in civil, family, and criminal matters, our courts took decisions on the basis of norms of international treaties.

Vereshchetin, Danilenko \& Mullerson, supra note 4, at 15-16. The recently published 1 KURS MEZHDUNARODNOGO PRAVA (International Law Course) 299-300 (R. Mullerson \& G. Tunkin eds. 1989), gives several examples of the application in Soviet courts of an agreement on international rail freight transportation concluded among socialist countries. See also R. MULLERSON, SOOTNOSHENIE MEZHDUNARODNOGO I NATSIONAL'NOGO PRAVA (The Relationship Between International and National Law) 76-77 (1982) [hereinafter SOOTNOSHENIE] (citing the same examples).

32. See Berman, The Comparison of Soviet and American Law, 34 IND. L.J. 559, 567 (1959).

33. See infra text accompanying notes $46-53$.

34. See Quigley, Law Reform and the Soviet Courts, 28 Colum. J. TRANSNAT'L L. 59, 67-69 (1990). 
rooted in the rule of law. While most states share some resistance to infringements upon sovereignty imposed by international law, Soviet jurists and diplomats have insisted to an almost paranoiac degree on maintaining doctrinal dogmas and procedural safeguards in order to prevent international legal obligations from being imposed on or applied against the Soviet Union, unless and until the duly authorized organs of the Soviet state have given formal consent. ${ }^{35}$ In contrast to the West, where direct judicial application of customary international law is well established, ${ }^{36}$ Soviet courts have never applied custom as a source of law.

There is no overarching principle in Soviet law to resolve conflicts between international and domestic law. ${ }^{37}$ Instead, there are piecemeal answers, found in some dozens of separate laws that refer to international treaties. ${ }^{38}$ Thus, there is no "later-in-time" rule comparable to the one endorsed by the U.S.

35. Thus, Soviet doctrine has traditionally favored treaties over custom as sources of international law. See G. TUNKIN, THEORY OF INTERNATIONAL LAW 133-37 (1974). Some commentators have identified the Soviet Union as strictly "dualistic" in its approach to the relationship between international and domestic law-that is, that it maintains a rigid separation between the two bodies of law unless and until the occurrence of an appropriate act that brings an international rule into the domestic system. A number of Soviet scholars reject this characterization, however. For an exposition of the trends among Soviet international lawyers, see KURS MEZHDUNARODNOGO PRAVA, supra note 31, at 272-82, 292-303; see also W. BUTLER, SOVIET LAW 397-98 (2d ed. 1988) (and authorities cited therein); SOOTNOSHENIE, supra note 31, at 75-82; Ginsburgs, The Validity of Treaties in the Municipal Law of the "Socialist" States, 59 AM. J. INT'L L. 523, 526-27 (1965). Traces may be found in Soviet writings of the idea that Soviet courts must apply international treaties in certain kinds of cases, regardless of the existence of an act transforming an international rule into a domestically applicable one. See I. BLISHCHENKo, MEZHDUNARODNOE I VNUTRIGOSUDARSTVENNOE PRAVO 230 (1960) (International and Internal Law), quoted in W. BUTLER, supra, at 397 (" $[A]$ national law and an international treaty have equal force on the territory of a State, and ... national courts are obliged to apply the international treaty just as a national law on the territory of the State."). But in view of the highly circumscribed sphere in which international treaties have actually been used as a judicial rule of decision, the Soviet approach contrasts sharply with that of a number of states, including the United States, that consider international law to be part of the "law of the land."

A trend that may eventually prove relevant to the application of international law in Soviet courts is the effort to involve the Soviet legislature more directly and substantially in foreign policy in general, and in the treaty process in particular. The extent to which the legislature will exercise oversight or control over the treaty process is still evolving. Soviet experts in international law have stressed the importance of bringing about the continuous and substantive involvement of the legislative branch in Soviet foreign policy-in particular, by specifying in the Constitution the types of treaties that would require parliamentary approval. See Vereshchetin \& Mullerson, supra note 4, at 17. If legislative participation in treatymaking becomes meaningful, there could be tangible gains for the democratization of Soviet foreign relations, and the possibilities for applying international treaties as part of domestic law might be enhanced.

36. See Paquete Habana, 175 U.S. 677 (1900).

37. Neither the Soviet Constitution nor the Law on Treaties, supra note 30 , contains any universal rule on resolving such conflicts. Rather, some 20 separate laws specify that they are to be interpreted in conformity with Soviet obligations under international treaties, but this is not all laws. See Ametistov, Problems of Relations Berween Imternational and National Law, and Burchak, Incorporating International Law into Domestic Law, both reprinted in THE MOSCOW CONFERENCE ON LAW AND ECONOMIC COOPERATION: FACULTY PRESENTATIONS 55, 57 (1990). But see W. BUTLER, supra note 35, at 397-98 (suggesting that the approach of according priority to international treaty obligations "would seem to represent a general statement of principle in Soviet law," but noting that because the approach is embodied only in some statutes and not in others, it may represent "a reserve guarantee in certain specific types of social relations rather than a universal rule in Soviet law"): see also Ginsburgs, supra note 35, at 540-43.

38. Examples of laws providing for the priority of international treaties, as well as of laws omitting any such provision. are given in W. BUTLER, supra note 35, at 398; see also Burchak, supra note 37, at 58. 
Supreme Court more than a century ago for resolving conflicts between treaties and federal statutes, ${ }^{39}$ nor is there anything like the approach of certain European countries, according to which international obligations are given hierarchical priority over domestic sources of law. ${ }^{40}$ Recently, certain Soviet scholars have expressed unhappiness with this state of affairs and have argued for a general rule establishing the priority of international obligations over conflicting domestic rules. ${ }^{41}$

Further complications stem from the current anarchic state of affairs between the Union on the one hand and the Soviet republics and subunits on the other. Until recently, there was no question of conflict between national policy embodied in a Soviet treaty and republican or local policy, because the central government had ample authority to declare and implement policy for the country as a whole. ${ }^{42}$ With the exception of treaties adopted separately by the Ukraine and Byelorussia as U.N. members, ${ }^{43}$ international treaties have entered into force for the USSR by virtue of undertakings made at the Union level. In declarations of sovereignty adopted within the last few years, however, most of the republics and a variety of smaller entities have denied the authority of the Union to impose law on them without their consent or over their explicit objections. ${ }^{44}$ If the disintegrative tendencies continue, the republics may begin to "pick and choose" among treaties according to the level of support that they enjoy within the republic. In that event, human rights treaties may actually be more likely to enjoy acceptance within the republics than other Soviet treaties. A striking pattern has emerged under which the sovereignty declarations and

39. See Whitney v. Robertson, 124 U.S. 190, 194 (1888). But see W. BUTLER, supra note 35, at 397 (citing Blishchenko to the effect that in event of a conflict between national legislation and an international treaty, "the enactment last in time governs").

40. See examples from European constitutions cited in L. HENKIN, R. PUGH, O. SCHACHTER \& H. SAIT, INTERNATIONAL LAW: CASES AND MATERIALS 141-44 (2d ed. 1987). European models are surveyed for possible application in the Soviet Union in Vereshchetin, Danilenko \& Mullerson, supra note 4, at 14-16.

41. Vereshchetin, Danilenko \& Mullerson, supra note 4, at 16-17. For discussion of the role of the newly created Committee of Constitutional Supervision in reviewing legislation for conformity to international human rights law, see infra text accompanying notes 54-71.

42. Although Soviet and American federalism differ markedly, under both systems the central government has enjoyed primacy in the field of foreign relations; treaties made by the USSR or by the United States would prevail over any conflicting law or policy of the Soviet republics or the American states. See U.S. ConST. art. VI, cl. 2; cf. Law on Treaties, supra note 30, art. 21. Under Article $\$ 0$ of the 1977 Constitution, the Union republics are given certain international powers denied to the states of the United States, including the right to conclude treaties, $c f$. U.S. CoNsT. art. I, $\$ 10$, cl. 1, but in practice there has been complete subordination of the republics to the Union in the field of external relations. In the cases in which certain Union republics did enter into international treaties, see infra note 43 concerning treaties of the Ukraine and Byelorussia, the Union itself has been a party to the same treaty. The discussion above concerning judicial implementation of treaties applies generally to all Soviet courts, including those in the republics. In contrast to the United States, where the supremacy clause directs state judges to apply treaties as the law of the land, courts in the Soviet republics have applied treaties only to the limited extent outlined above.

43. These two Soviet republics are parties to the same U.N.-sponsored human rights treaties as the USSR itself. See HUMAN RIGHTS: STATUS OF INTERNATIONAL INSTRUMENTS, supra note 15.

44. The deciarations take various forms and do not necessarily purport to oust all Soviet laws. Examples of the declarations are cited infra note 45. 
constitutional drafts of the various republics give special prominence to norms of international law protecting human rights. ${ }^{45}$

\section{B. Current Trends in the USSR}

With this overview of Soviet approaches to problems in the domestic application of international law, let us now consider some of the developments since Mikhail Gorbachev set in motion far-reaching changes in the domestic and foreign policies of the Soviet Union. Along with perestroika and glasnost', the Soviet leadership under Gorbachev committed itself to the building of a state based on law-pravovoe gosudarstvo in Russian. ${ }^{46}$ The commitment involves a major change in philosophical orientation that travels some distance toward the use of law to curb arbitrariness and abuses of power. While recent developments have called into question the willingness and ability of the Soviet regime to fulfill this commitment, it remains a key element of the articulated program of the Soviet leadership ${ }^{47}$ as well as of the various republics. ${ }^{48}$

\footnotetext{
45. The following examples illustrate the emphasis on international protection of human rights in declarations and constitutions recently adopted or proposed by the republics:

Russian Soviet Federated Socialist Republic (RSFSR), Declaration on the State Sovereignty of the RSFSR: "10. All citizens [and other persons] are guaranteed the rights and freedoms envisaged by the RSFSR Constitution, the USSR Constitution, and universally recognized norms of international law." Foreign Broadcast Information Service, Soviet Union 90-115, June 14, 1990, at 102, 103 [service hereinafter FBISSOVl: see also id. at point 14 ("The RSFSR states its adherence to the universally recognized principles of international law ....").

RSFSR, Draft Constitution, art. 1.3(2) (on file with author): "Human rights in the Russian Federation are guaranteed in conformity with generally recognized principles and norms of international law." Ukrainian Soviet Socialist Republic, Declaration on the Ukraine's State Sovereignty:

IV. [Citizens of the Ukrainian SSR] are guaranteed rights and freedoms envisaged by the constitution of the Ukrainian SSR and norms of international law recognized by the Ukrainian SSR ....

X. . . . The Ukrainian SSR admits the superiority of human values over class values, and the priority of generally-acknowledged norms of international law over norms of inner state law. FBIS-SOV 90-139, July 19, 1990, at 90-91.

Latvian Declaration of Independence: “[T] he Latvian SSR Supreme Soviet decides: 1. To recognize the priority of basic principles of international law over the norms of state rights ....

8. To guarantee to [citizens and permanent residents of Latvia] political liberties corresponding to generally recognized international human rights norms." FBIS-SOV 90-088, May 7, 1990, at 99-101.

Estonian Constitution:

The provisions of the International Covenant on Economic, Social and Cultural Rights and of the International Covenant on Civil and Political Rights and of other international pacts and declarations on the protection of human rights and civil rights, which have received universal recognition among states of the world and have been ratified by the USSR, are an inalienable part of the legal system of the Estonian Republic.

Law on the Introduction of Changes and Additions into the Constitution (Fundamental Law) of the Estonian USSR, quoted in Juviler, Guaranteeing Human Rights in the Soviet Context, 28 COLUM. J. TRANSNAT'L L. 133,139 n.25 (1990).

46. On the concept of pravovoe gosudarstio, see generally HELSINKI WATCH, TOWARD THE RULE OF LAW: SOVIET LEGAL REFORM \& HUMAN RIGHTS UNDER PERESTROIKA 7 n.2 (1989); Beissinger, The Party and the Rule of Law, 28 COLUM. J. TRANSNAT'L L. 41 (1990); Iakovlev, Constitutional Socialist Democracy: Dream or Realiny?. 28 Colum. J. TRANSNAT'L L. 117 (1990).

47. The draft of a new Union treaty proclaims that the uniting republics would "strive for the creation of a rule-of-law state (pravove gosudarstro)." Union Treaty Draft, supra note 2, 5th point, at 4.
} 
On the international plane, the Soviet leadership has been pursuing a program known as "new political thinking" (novoe politicheskoe myshlenie), which has been articulated in major statements by Mikhail Gorbachev addressed to the United Nations and to the international community as a whole. ${ }^{49}$ Gorbachev's speeches underscore that "it is necessary that national legislation and administrative rules in the humanitarian sphere everywhere be brought in accordance with international obligations and standards." 50 While aimed in part at the problem of ensuring compliance by all states with agreed rules of interstate conduct, Gorbachev's exhortation endorsing "a system of universal law and order ensuring the primacy of international law in politics"51 also obviously applies to the international law of human rights.

Soviet legal scholars have elaborated the concept of "the primacy of international law in politics" in two mutually reinforcing directions; both are relevant to the strengthening of the legal implementation of human rights. On the one hand, the leading Soviet scholar of international law has asserted that the domestic rule of law will lead to greater compliance with international law:

Beyond doubt a State in which democracy and legality predominate and respect for human rights is ensured can be expected to respect international law in the international arena more than a State in which arbitrariness predominates. Therefore, the existence of the greatest possible number of rule-of-law States which can set the tone of international life is an important prerequisite for the primacy of international law in politics. $^{52}$

Viewing the linkage from the other direction, Soviet jurists have also emphasized that establishing the primacy of international human rights law could help consolidate the domestic rule of law within the Soviet Union. ${ }^{53}$

Tangible actions have been taken to integrate the pravovoe gosudarstvo program with international human rights. Of potentially great significance is the creation of a Committee of Constitutional Supervision that has the authority to review legislation and other normative acts for their conformity both to the

48. See, e.g., Article 1.1 of the Draft Constitution for the RSFSR, supra note 45 , which provides as its first proposition that the "Russian Federation is a sovereign, democratic, social, and law-based state (pravovoe gosudarstio) ...."

49. The first such speech was published in Pravda and Izvestiia on September 17, 1987 and was subsequently circulated as a U.N. document. The address given on December 7, 1988 to the U.N. General Assembly is published as U.N. GAOR, 43d Sess., 72d plen. mtg., at 2, U.N. Doc. A/43/PV.72 (1988). Of the many important elements of this program, which include the development of a comprehensive system of global security through the United Nations, I will be concerned here only with those that pertain to the enhancement of human rights and the rule of law.

50. Pravda, Sept. 17, 1987, at 1.

51. Id. at 1 .

52. Tunkin, On the Primacy of International Law in Politics, in PERESTROIKA AND INTERNATIONAL LAW 5, 9 (W. Butler ed. 1990).

53. See Vereshchetin \& Mullerson, supra note 4, at 9-10. 
Soviet Constitution and, interestingly, to international human rights norms. ${ }^{54}$ While not a court, ${ }^{55}$ the Committee represents an important step toward applying constitutional control to institutions of governmental power. Although this system differs from the U.S. model in several key respects, including the fact that the Soviet legislature may overrule the Committee's findings, ${ }^{56}$ the potential of the Committee should not be minimized.

In the area of international human rights law, the Committee may exercise supervisory control according to the following provisions:

Art. 18. . . A conclusion of the [Committee] contains a finding as to whether the act, draft act or individual provisions thereof does or does not conform to the USSR Constitution or the USSR laws, or, when appropriate, to the USSR's international commitments as well.

Art. 21.... A conclusion of the [Committee] stating that a particular normative legal act or individual provisions thereof violates basic human rights and liberties codified in the USSR Constitution and in international acts to which the USSR is a party entails the voiding of this act or individual provisions thereof from the moment that the Committee's conclusion is adopted. ${ }^{57}$

54. Law on Constitutional Review, 42 CuRRENT Dig. Soviet PREss, No. 9, Apr. 4, 1990, at 13, translated from Pravda, Dec. 26, 1989, at 3, and Izvestiia, Dec. 26, 1989, at 1, 3 . The cited translation uses the term "Constitutional Review Committee" to refer to the body that I have called the Committee of Constitutional Supervision. The term "Supervision" is semantically closer to the Russian nadzor (from the roots for "over" and "see") and avoids connotations of the term "review" in U.S. constitutional jurisprudence. See text accompanying note 56 infra.

55. To date, no powers of constitutional review have been vested in Soviet courts, but there is ongoing debate over whether such a reform should be instituted. In a recent speech in Washington, D.C., Yevgeny Smolentsev, chairman of the USSR Supreme Court, stated: "Many Soviet jurists including myself do believe that the power of constitutional review should be vested in the highest judicial tribunal of the nation." $A n$ Evolving System of Soviet Justice, Legal Times, Sept. 17, 1990, at 15; see also Iakovlev, supra note 46, at 127-28 (recommending that highest courts of union republics should perform review for constitutionality).

56. See Law on Constitutional Review, supra note 54, arts. 19-22. The Committee's advice that an act is unconstitutional has the effect of suspending its operation, but the Committee's conclusions may be rejected by the Soviet legislature, with the Congress of People's Deputies having the final decision. Advice may be rendered on draft laws as well as on acts that have already entered into force. Concerning the effect of advice that an act violates international obligations of the USSR, see infra text accompanying note 71 .

57. Law on Constitutional Review, supra note 54, arts. 18,21 (emphasis added). The Committee also has authority to review treaties for conformity to the Constitution, pursuant to the following provisions of the Law on Constitutional Review:

Art. 10. [The Committee] exercises review over the conformity to the USSR Constitution and to USSR laws adopted by the Congress of USSR People's Deputies and the USSR Supreme Soviet of . . . international treaty and other commitments of the USSR and the Union republics that are presented for ratification or confirmation.

Art. 12. [The Committee] accepts a question for consideration ... (4) [under specified instructions from organs empowered to request opinions] with respect to ... international treaty and other commitments of the USSR and the Union republics.

Id. arts. 10,12. Conceivably, the Committee could find that a treaty proposed for ratification (or possibly even one that has already been ratified) would violate the Soviet Constitution. Such a finding could have either positive or negative implications for the protection of human rights within the Soviet Union, depending on the nature of the treaty in question and the constitutional provision invoked against it. If the Committee finds that an actual or proposed treaty would violate the Soviet Constitution, the nonconformity could be resolved by changing the Constitution, which is easier to do in the Soviet system than in the American system. 
In its first six months of operation the Committee has relied on international norms protecting human rights in more than half of its decisions, ${ }^{58}$ including the following:

Labor disputes-judicial appeals: ${ }^{59}$ The Committee took note of Articles 7 and 8 of the Universal Declaration and Article 2(3)(b) of the International Covenant on Civil and Political Rights, concerning equality of rights before the law and the right of every person to an effective remedy for violation of rights.

Residence permits: ${ }^{60}$ The Committee cited Article 13 of the Universal Declaration and Article 12 of the International Covenant on Civil and Political Rights, concerning freedom of movement and choice of residence within a state, and underscored that the International Covenant also governs the derogability of these rights. The Committee also referred to the international principle of equal access to education and noted that prolonged division of families would violate not only the Soviet Constitution and laws, but also international norms.

Presumption of innocence: ${ }^{61}$ The Committee took note of Article 11(1) of the Universal Declaration and Article 14(2) of the International Covenant on Civil and Political Rights, concerning the right of every accused to be presumed innocent until proven guilty according to law in a public trial.

Alcoholism and drug addiction. ${ }^{62}$ The Committee considered that measures for compulsory treatment in health facilities conflicted with Article 2(3)(a) of the International Covenant on Civil and Political Rights, concerning the right to an effective remedy for the violation of rights. The Committee also found a violation of Article 7(d) of the International Covenant on Economic, Social

58. Decisions of the Committee are published in Vedomosti Verkhovnogo Soveta SSSR and are cited below according to their 1990 Vedomosti item number.

At its first official meeting, the Committee decided to consider four questions on its own initiative, and two of these involved examination of international human rights obligations. See Stepovoi, Constifutional Committee Makes Decisions, 42 CuRRENT DIG. SOVIET PRESS, No. 37, Oct. 17, 1990, at 27, translated from Izvestiia, Sept. 15, 1990, at 1; Stepovoi, Guarding the Constitution, 42 CURRENT DIG. SOVIET PRESS, No. 20, June 20, 1990, at 26, translated from Izvestiia, May 16, 1990, at 2.

During the first six months of operation, the Committee considered a total of 10 decisions; 7 invoke human rights norms. Each decision would merit a detailed discussion of the substance of the rights addressed, as well as of such questions as the basis on which the Committee's jurisdiction was invoked and the treatment of the relationship between constitutional jurisprudence and other sources of law. Specialists in international human rights law might well find the substance of some of the Committee's decisions surprising and perhaps even overly zealous. My comments must be confined to the aspects of the published decisions that specifically cite international obligations concerning human rights.

59. 2 Vedomosti SSSR, No. 27, item 524 (1990). In discussing this decision in a press interview, the deputy chairman of the Committee said that "international acts provide for exceptions with regard to court appeals only for persons who hold posts of a political nature or posts requiring special confidentiality." Constitutional Court Status Urged, FBIS-SOV 90-244, Dec. 19, 1990, at 49, 50.

60. 2 Vedomosti SSSR, No. 39, item 773 (1990); 2 Vedomosti SSSR, item 1004 (1990); see also Committee Issues Constitutionality Decisions, FBIS-SOV 90-213, Nov. 2, 1990, at 40-41.

61. 2 Vedomosti SSSR, No. 39, item 775 (1990).

62. 2 Vedomosti SSSR, No. 47, item 1001 (1990). The deputy chairman of the Committee stated: "We deemed the existing legislation on compulsory treatment for alcoholics does not comply with the USSR Constitution and international law. Tens of thousands of sick people who have committed no crime are now essentially being kept imprisoned." FBIS-SOV-90-244, Dec. 19, 1990, at 50; see also FBIS-SOV-90-213, Nov. 2, 1990, at $40-41$. 
and Cultural Rights, concerning rest, leisure, and periodic holidays with pay, arising out of denial to workers of leave for treatment. Interestingly, with respect to a measure purporting to require Soviet citizens to take care of their health, the Committee said that "such an obligation is not provided for in the Constitution of the USSR, nor in international acts on human rights, and cannot be secured by measures of a compulsory character."

RSFSR prohibition on joint holding of posts: ${ }^{63}$ The Committee examined legislation of the Russian Republic that prohibited holding a leadership position in any governmental organ while simultaneously fulfilling any other responsibility, including with respect to political or social organizations. The Committee found conflicts with the following international acts: Articles 22 and 25 of the International Covenant on Civil and Political Rights, concerning rights of free association and rights to take part in government and to be elected to office; Article 8 of the International Covenant on Economic, Social and Cultural Rights, concerning the right to form trade unions; Articles 2, 3, and 8 of a convention of the International Labor Organization concerning freedom of association; and Articles 7.5 and 7.9 of the CSCE Copenhagen Document. ${ }^{64}$

Unpublished acts concerning rights, freedoms, and obligations: ${ }^{65}$ The Committee referred to "international acts on human rights" in ruling that normative acts touching on rights and obligations must be published.

In every case to date in which the Committee has relied on international instruments, it has done so in reference to parallel provisions in the Soviet Constitution; no case has yet rested on international human rights law alone. ${ }^{66}$ Placing international human rights law alongside the Soviet Constitution tends to demonstrate their congruence; the two sources of rights mutually reinforce each other. Significantly, however, the Committee's work also indicates a willingness to construe the Soviet Constitution in a manner that will promote its consistency with international legal obligations. Accordingly, the Committee

63. 2 Vedomosti SSSR, No. 47, item 1002 (1990). The deputy chairman of the Committee said: "I would particularly single out our committee's negative conclusion on the decision by the [RSFSR legislature] banning the joint holding of the posts of leaders of a state organ of power or management with any other post, including political or sociopolitical organizations .... [S]uch a ban is regarded by international pacts as inadmissible discrimination on political grounds." FBIS-SOV 90-244, Dec. 19, 1990, at 50; see also FBIS-SOV 90-213, Nov. 2, 1990, at 40-41.

64. Supra note 21 .

65. 2 Vedomosti SSSR, No. 50, item 1080 (1990).

66. The significance of this pattern may become clearer as the Committee's work proceeds. At this early stage, I would venture the tentative hypothesis that the Committee desires to place primary emphasis on the Soviet Constitution in order to strengthen respect for that document and to aid in inculcating a culture of constitutional review.

In some of the cases referred to above, international instruments are cited in the paragraphs leading up to the dispositive paragraphs, while the dispositif is formulated in terms of nonconformity to the relevant constitutional provision. Examples are the decisions on labor disputes and on presumption of innocence. See supra notes 59,61 and accompanying text. In other cases, however, both the preambular material and the dispositif cite international documents. Examples include the alcoholism decision, see supra note 62 and accompanying text, and the decision concerning the RSFSR ban on joint posts, see supra note 63 and accompanying text. 
has drawn attention to provisions of international instruments that are more specific or more protective of rights than the Soviet Constitution. ${ }^{67}$

An important issue is whether the Committee's jurisdiction over international human rights matters extends beyond formally ratified treaties to include the conformity of domestic acts with the Soviet Union's commitments made in the Universal Declaration and in the Conference on Security and Co-operation in Europe, including at the Helsinki, Vienna, and Copenhagen meetings. ${ }^{68}$ Despite the reluctance of the signatories to undertake legally binding commitments at the time of adoption of these documents, the Soviet Union has apparently moved a long way toward giving them legal force through the domestic institution of the Committee. The law defining the Committee's jurisdiction uses formulations with respect to international obligations that appear on their face to go beyond ratified treaties. ${ }^{69}$ The Committee has taken a generous view of its own mandate and has considered various sorts of "international acts," including the Universal Declaration and CSCE documents. ${ }^{70}$

According to Article 21 of the Committee's statute, a finding of a violation of "basic human rights and liberties codified in the USSR Constitution and in international acts" entails the "voiding" of the domestic act. In other cases, according to the same Article, the domestic act is suspended until the indicated nonconformity is removed. ${ }^{71}$

\section{JUDiCIAL APPLICATION OF INTERNATIONAL HUMAN RIGHTS LAW}

67. An example is the decision on residence permits, see supra note 60 and accompanying text, which quoted verbatim the provision of the International Civil and Political Covenant stressing that the rights to freedom of movement and free choice of residence "shall not be subject to any restrictions except those which are provided by law, are necessary to protect national security, public order (ordre public), public health or morals or the rights and freedoms of others, and are consistent with the other rights recognized in the present Covenant."

68. As noted supra note 22 , these instruments have generally been viewed as embodying political rather than legal commitments, and the Soviet Union (like other states, including the United States) has endorsed them without all the formalities of treaty ratification.

69. The terms "international commitments" and "international acts," used in the provisions quoted in text accompanying note 57 supra, are consistent with this broader interpretation.

70. The ruling on the RSFSR ban on joint posts, see supra note 63 and accompanying text, cited the Copenhagen Document, supra note 21.

71. It is not clear whether the provisions that authorize the legislature to overrule the Committee's conclusions of nonconformity apply when the offending domestic act is "voided" for noncompliance with international human rights law; the act is open to the interpretation that such conclusions would be definitive and not merely advisory. Arguably, Article 22, which provides for the possibility of rejection of the Committee's conclusions by specified votes of the legislature, does not apply in cases where the nonconformity pertains to domestic acts in violation of "international acts to which the USSR is a party" concerning "basic human rights and liberties." This interpretation is supported both by the distinction between "suspension" and "voiding" found in Article 21, and by the fact that Article 22 refers only to nonconformities with "the USSR Constitution or a USSR law," not to nonconformities with international acts concerning human rights. Proposals for clarifying and strengthening the role of the Committee with respect to its authority in the sphere of international human rights have been made by experts in international law. See. e.g., Vereshchetin, Danilenko \& Mullerson, supra note 4, at 18. 
I believe that the effort to build a law-based state in the Soviet Union (or successor entities) should go beyond the limited constitutional review described above. Soviet courts should give direct effect to international human rights law, and could do so consistently with contemporary Soviet notions of legitimacy. In making this suggestion, I am well aware that the United States has not yet gone very far down this path. It is perhaps ironic that the Soviet Union may be poised for greater progress toward domestic application of international human rights law than is the United States. U.S. ratification of comprehensive human rights treaties would, of course, lend greater legitimacy to judicial application of international human rights law here.

Considerations of both an institutional and a substantive character underlie my position that Soviet courts should apply international human rights law. On the institutional level, I believe that there are parallel and complementary roles for courts and for the Committee on Constitutional Supervision; reliance on the latter will not suffice to ensure compliance with international obligations. ${ }^{72}$ Important as the Committee on Constitutional Supervision may be (or may become), its jurisdiction cannot be invoked by the ordinary citizen affected by governmental action. Rather, only certain designated organs and officials may request the Committee to take up a matter. ${ }^{73}$ Judicial remedies should be structured so that the individual can apply to a body in or near her own hometown for redress against unlawful official action. ${ }^{74}$

Undoubtedly, the Committee as an institution has certain advantages over local courts in matters involving international law, and accordingly I stress that the functions of the two organs must be complementary. It is to be expected-and early experience bears out this prediction-that members of the

72. Many have argued that constitutional control cannot achieve full effectiveness in the USSR unless review for constitutionality is carried out by a court or courts. In current debates in the Soviet Union, some have called for the constitutional review function to be lodged in the judiciary-at least in the Supreme Court, if not the lower courts. The incumbent chairman and deputy chairman of the Committee on Constitutional Supervision favor transformation of the Committee into a "Constitutional Court," and this approach is taken in the draft Union Treaty now under discussion. See FBIS-SOV 90-238, Dec. 11, 1990, at 41,43; FBIS-SOV 90-244, Dec. 19, 1990, at 49-50. While this Essay is not the place to explore the issues concerning different forms of constitutional review and their suitability for the Soviet Union, I would underscore the important role of courts in ensuring legality of official action wholly apart from the question of which body or bodies should have authority to review legislative acts for constitutionality.

73. Questions may be submitted to the Committee by the Congress of People's Deputies and the Supreme Soviet or certain subgroups and officials thereof, by the Union republics' supreme bodies of state power, and by certain executive and judicial organs and other designated bodies. There is also a procedure for the Committee to take up questions on its own initiative. See Law on Constitutional Review, supra note 54, arts. 12-13. The USSR President also may present questions to the Committee. See Law on Establishing the Post of President of the USSR and Making Changes to the USSR Constitution, 42 CURRENT DIG. SOVIET PRESS, No. 14, May 9, 1990, at 20, translated from Pravda, Mar. 16, 1990, at 1, 3 and Izvestiia, Mar. 16, 1990, at 2-3 (amending Article 124 of Constitution). This jurisdictional feature was a deliberate policy choice, and I do not think that it should be revisited at this early stage. Eventually it may become possible to consider broadening the jurisdiction of the Committee (or court that succeeds to its functions) to include review for constitutionality upon the petition of individuals along the American model, but this issue should be kept analytically distinct from the issue of supervision of governmental action discussed in the text.

74. It would not be advisable to overwhelm the Committee with petitions from all over the country, nor to require individuals to apply to Moscow for review of actions of local authorities. 
Committee will be elite professionals, who are relatively much more likely than the average judge to have had exposure to the jurisprudence and culture of international human rights (including, among other things, by virtue of contacts with foreign lawyers). ${ }^{75}$ Moreover, the establishment of the Committee has taken place with careful attention to structural features conducive to independent judgment, ${ }^{76}$ while the work of attempting to reconstruct the Soviet judiciary in the interests of independence is just beginning. One may envision the eventual evolution of a system under which the Committee, or a successor court of comparable centralized character, would elucidate principles weaving international human rights law into the fabric of Soviet jurisprudence (constitutional and otherwise), and courts throughout the country would then apply those principles to the myriad concrete cases that come before them.

On the substantive level, review of official actions for conformity to international law would strengthen the level of protection for individuals beyond that provided by the Soviet Constitution and laws. The international human rights documents endorsed by the USSR are more detailed and demanding than the relevant provisions of the Soviet Constitution. International human rights law resists the tendency of Soviet constitutional law to place the interests of the state above the rights of individuals. ${ }^{77}$ While comprehensive reform of the Soviet Constitution and laws to eliminate inconsistencies with international human rights law theoretically would be possible, acknowledging the priority of international human rights law over contrary domestic acts could accomplish the same result in a simpler and more straightforward fashion. ${ }^{78}$

The reasons why Soviet jurisprudence to date has not been receptive to the direct application of international law need not preclude judicial enforcement of international human rights law in the future that is now unfolding. Here it may be enlightening to contrast some aspects of the U.S. and Soviet attitudes toward legitimacy of lawmaking and judicial activities, to the extent that they may bear on domestic application of human rights law.

75. The author's views concerning the point in the text are shaped by recent encounters in Moscow and New York with a variety of Soviet legal and judicial personnel.

76. The Committee's chairman has drawn attention to the importance of structural features guaranteeing the independence of the Committee, or future constitutional court, from any of the bodies whose work it might supervise. FBIS-SOV 90-238, Dec. 11,1990, at 42-43.

77. Compare the general exception in Article 39 of the Soviet Constitution ("Enjoyment by citizens of their rights and freedoms must not be to the detriment of the interests of society or the state, or infringe the rights of other citizens.") with, e.g., Article 4 of the International Covenant on Civil and Political Rights (containing carefully circumscribed derogations). See also KONST. SSSR arts. 59, 62, 65 (1977). Developments in Soviet constitutional law may narrow the gap somewhat, but it is premature to be overly optimistic.

78. $C f$. Vereshchetin, Danilenko \& Mullerson, supra note 4, at 20 (recommending constitutional rule that Soviet laws are to be applied in conformity with international obligations of USSR, including those undertaken through Helsinki process); Vereshchetin \& Mullerson, supra note 4, at 10 (noting huge task of bringing Soviet legislation into conformity with international obligations).

The situation is thus quite different from that found in the United States, where judicial review is available to individuals under substantive constitutional standards that are usually at least as rigorous as the requirements of international law. The more effective an existing constitutional system in ensuring enforcement of human rights, the less it needs to allow individuals to rest their claims on international law. 
As Professor Brilmayer underscores in this symposium, part of the reluctance of U.S. courts to apply international law may be attributable to a concern over the absence of the majoritarian imprimatur that is the touchstone of legitimacy in the American tradition. ${ }^{79}$ International human rights law implicates this concern in problematic fashion. Those who resist applying international jurisprudence argue that human rights advocates should address their demands to the political branches instead of to the courts: until a mobilization of constituencies in support of ratification of human rights treaties, the ordinary outcome of political compromises within the United States would prevail. Moreover, the subject matter of international human rights law includes areas where controversy over constitutional review in the United States is already quite acute. In recent death penalty cases ${ }^{80}$ for example, human rights advocates invoked international jurisprudence in a sphere where passions already ran high about the legitimacy of using "countermajoritarian" notions, not rooted in constitutional text or original intent, to invalidate state statutes. In my view, international human rights law is no more "countermajoritarian" than familiar techniques of constitutional review, ${ }^{81}$ but its substantive scope is similar enough to the Bill of Rights to bring into play all the anxieties about judicial activism that surface in highly politicized contexts such as the death penalty.

By contrast, majoritarianism has not yet taken hold as the philosophy by which the legitimacy of lawmaking activity should be judged in the Soviet Union. To be sure, the political-legal reforms of the perestroika period have placed greater emphasis on lawmaking by a quasi-representative legislature than was the case during the decades when the Communist Party of the Soviet Union enjoyed primacy both in the written constitution and in actuality. Developments toward pluralism and majoritarianism in Soviet lawmaking are surely to be applauded and encouraged-through international human rights law among other means ${ }^{82}$-but until majoritarian institutions are firmly in place and capable of producing legislation reflective of the will of the majority of the electorate, legitimacy must be judged by criteria other than parliamentary endorsement. The "majoritarian" credentials of the Soviet Parliament to date must be viewed with considerable skepticism, not only on formal grounds pertaining to the methods for selection of members of its chambers, but also because of the intense struggle over whether any political body at the level of

79. Brilmayer, International Law in American Courts: A Modest Proposal, 100 YALE L.J. 2277, 2281 83 (1991).

80. E.g., Stanford v. Kentucky, 492 U.S. 361 (1989): Thompson v. Oklahoma, 487 U.S. 815 (1988).

81. Justice O'Connor's ambivalence in the two juvenile death penalty cases cited supra notes 24 and 80 is suggestive. Would contemporary majorities in state legislatures really vote to impose the death penalty on teenagers, especially if they knew that the overwhelming trend-not only in advanced democracies, but in the world at large-is to the contrary?

82. See, e.g., Universal Declaration of Human Rights, sipra note 7, art. 21(3); International Covenant on Civil and Political Rights, sipra note 9, art. 25; Copenhagen Document, supra note 21, paras. 3, 5.1-5.4 (all providing, with varying degrees of specificity, for government based on will of people expressed through periodic and genuine elections). 
"the Union" can reflect the will of the constituent peoples who clamor for reallocation of effective power to the republics or even smaller units. In the absence of political institutions that meaningfully represent working majorities, the "countermajoritarian" objection to judicial activity is misplaced. ${ }^{83}$ Indeed, the very weakness of majoritarian processes to date makes it all the more appropriate to consider whether courts could play a role in enforcing the civil and political rights that form the foundation of a functioning democracy. ${ }^{84}$

The old foundations of Soviet legitimacy have crumbled and new ones are not yet established. It seems inappropriate in this time of profound political change to argue from traditional premises about legitimacy that may not respond to contemporary yearnings of the peoples of the Soviet Union. Thus, I would not place too much weight on the fact that the use of Soviet human rights treaties as a source of domestic law would be consistent with positivist legal theories that have characterized Soviet jurisprudence in the past. To illustrate the point, should we care very much that Soviet treaty obligations were undertaken with all the formalities of state consent that conferred one kind of legitimacy under the long-prevailing Soviet theory of legal obligation? Soviet consent to international human rights documents represented a powerful rhetorical point during the period of strenuous efforts to induce compliance with them, but in my opinion governmental consent, without more, is of dubious relevance in the current period of revolutionary change. The fact that their rulers once consented to a legal norm does not suffice to legitimate the norm in the eyes of the Soviet peoples today. The basis for the legitimacy of international human rights law is that it expresses fundamental values which enjoy support from the peoples of the Soviet Union in the present and for the enduring future, ${ }^{85}$ legitimacy derives from the moral force of the content of the norms, and not from historically grounded consent.

If Soviet courts were to begin to apply international human rights law and were to encounter acquiescence or perhaps even applause, the effort could be self-legitimizing. It is not necessarily farfetched to suggest that the Soviet

83. Thus, I disagree with the U.S. Attorney General, who has written:

Whether judicial review is conducted by a court or by a [Committee of Constitutional Supervision], a "Madisonian dilemma" arises, whereby a nonelected body would be empowered to nullify democratically promulgated legislation. After years of absolutism one temptation inexorably facing the new judiciary or [Committee] would be to advance reforms beyond those contained in legislation. However, it is democracy and the rule of consent by the governed that legitimizes any law. Any judicial review extending or rejecting legislation based on the vision, no matter how well-meaning, of one individual or group of individuals acting as Platonic guardians could weaken the rule of law, the democratic spirit, and even the legitimacy of the new Soviet regime.

Thornburgh, The Soviet Union and the Rule of Law, FoREIGN AFF., Spring 1990, at 13, 21-22. This passage assumes the existence of viable Soviet democratic institutions-an assumption that will be questionable for some time into the future - and also overlooks the potential role of courts (or the Committee of Constitutional Supervision) in strengthening majoritarian processes.

84. $C f$. J. ELY, DEMOCRACY AND DISTRUST (1980) (articulating a role for courts in strengthening democratic processes).

85. See supra note 45 (declarations of sovereignty and related documents). 
people might embrace judicial application of international human rights law as more congenial to their current needs than the circumscribed role that courts have played in Soviet society in the past. ${ }^{86}$ To be sure, no movement in this direction will be successful in the absence of a considerable strengthening of independence of the judiciary and cultivation of a legal culture of judicial supervision of official action. But if the fledgling efforts at judicial reform take root and flourish, Soviet judges might look to international human rights law-which after all is fully codified and readily accessible-as the society gropes for new institutions to strengthen the rule of law.

\section{CONCLUSION: A CHALLENGE FOR THE UNITED STATES?}

The end of the Cold War provides an ideal opportunity for reconsidering the problem of the application of international human rights law in the United States. Professor Brilmayer's article takes a step in the right direction by focusing attention on the propriety of judicial consideration of relations between the state and the individual, and by dispelling some of the spurious objections to judicial enforcement of international law that surface from time to time. Her refutation of "countermajoritarian objections" to judicial application of international law is compelling; indeed, she might have added that in recent cases in which claimants sought to rely on international human rights law in U.S. courts, the challenged policies were not those of Congress but of executive agencies or of state legislatures acting ambiguously in the far-distant past. ${ }^{87}$ International human rights law presents the kinds of "vertical" issues ${ }^{88}$ that should be well-suited for judicial application in the United States, in cases based on customary international law as well as in treaty cases.

While I personally favor an active role for U.S. courts in applying and thereby shaping customary international law, I also believe that there is much to be gained by endorsing the written expression of international human rights law through the treaty vehicle. Action by the Senate on the human rights treaties that have been pending before it for more than a decade would give aggrieved persons a surer remedy than now exists in the current state of

86.

Soviet legal scholarship has always emphasized that international human rights treaties obligate signatories to ensure the applicable human rights and freedoms. However, until now, Soviet scholars have unjustifiably advocated that these documents do not represent rights directly enforceable by the individual. This approach has been excessively legalistic. A citizen of a state based on the rule of law has the right to demand that state agencies observe voluntarily adopted international obligations which directly affect the individual's interests.

Vereshchetin \& Mullerson, International Law in an Interdependent World, 28 COLUM. J. TRANSNAT'L L. 291, 300 (1990); Vereshchetin \& Mullerson, supra note 4, at 10.

87. See, e.g. Thompson v. Oklahoma, 487 U.S. 815, 826-28 \& $n .26$ (1988) (state legislation failed to set minimum age for death penalty); $i d$. at $849-55$ ( $\left({ }^{\prime}\right.$ Connor, J., concurring) (expressing doubt that contemporary state legislatures would vote to execute persons whose crimes were committed before age 16): Garcia-Mir v. Meese, 788 F.2d 1446 (11 th Cir.), cert. denied sub nom. Ferrer-Mazorra v. Meese, 479 U.S. 889 (1986) (challenging policy of Immigration \& Naturalization Service).

88. See Brilmayer, supra note 79 , at 2295-99 \& passim. 
uncertainty about customary law. Furthermore, full U.S. participation in human rights treaties is the best way to give us the moral and legal standing to influence trends toward enforcement of human rights in the former Soviet bloc.

U.S. skittishness about international human rights treaties has always seemed irrational to me. It is not necessary here to rehearse the arguments of proponents or opponents except to the extent that they may relate to Soviet positions. In that connection, I would note the following selected aspects of the arguments of some of the objectors. It has been said that the participation of the Soviet Union and other autocratic states is ipso facto proof of the worthlessness of these documents, because those states have hypocritically endorsed them with no intention of compliance and no expectation of sanction for violation. It has been said that international instruments embody socialistic notions that are not really "rights" at all, such as the "right" to a job or to social security or to education or to health care. It has also been said that the Soviet Union and other antagonists of the United States would exploit U.S. adherence for propagandistic uses of their own, as by fomenting dissension in Puerto Rico or on American Indian reservations in the United States. By relying on these and other arguments that presuppose continued ideological struggle between two hostile blocs, opponents have prevented the most important human rights treaties from becoming part of "the supreme Law of the Land," 89 and the few that have been allowed to squeak by are fettered with debilitating reservations aimed at minimizing their effectiveness as law in the United States. ${ }^{90}$

These objections never withstood scrutiny even during the height of the Cold War, and today they carry no force whatsoever. The Soviet Union, after years of paying mere lip service to human rights instruments, is now starting to take the obligations seriously. The human rights idea has revolutionized the Soviet Union and Eastern Europe, and the need to strengthen the legal mechanisms for giving effect to that idea is urgent. By fully accepting international human rights law as part of U.S. law, the United States can set a new standard for emulation in the courts of its former nemesis.

89. U.S. CONST. art. VI, cl. 2.

90. The Senate's consent to ratification of the Genocide Convention contained the following reservation: "[N]othing in the Convention requires or authorizes legislation or other action by the United States of America prohibited by the Constitution of the United States as interpreted by the United States." S. ExEC. REP. No. 2, 99 th Cong., 2d Sess. 26 (1985), reprinted in 80 AM. J. INT'L L. 612, 621 (1986). The Senate also took the view that the Genocide Convention should be non-self-executing; that is, it would not be operative in U.S. courts apart from its implementing legislation. See id. 